\title{
The morphological and phytochemical studies on the effect of acute and recurrent irradiation in Celosia cristata seeds
}

\author{
SYARIFAH IIS AISYAH ${ }^{1, \vartheta}$, IZZATUL MUHALLILIN ${ }^{1}$, DEWI SUKMA ${ }^{1}$, WARAS NURCHOLIS ${ }^{2,3, v v}$ \\ ${ }^{1}$ Department of Agronomy and Horticulture, Faculty of Agriculture, Institut Pertanian Bogor. Jl. Meranti, Kampus IPB Darmaga, Bogor 16680, West \\ Java, Indonesia. Tel./fax.: +62-251-8629353, `email: syarifah@apps.ipb.ac.id \\ ${ }^{2}$ Department of Biochemistry, Faculty of Mathematics and Natural Sciences, Institut Pertanian Bogor. J1. Agatis, Kampus IPB Darmaga, Bogor 16680, \\ West Java, Indonesia. Tel./fax.: +62-251- 8423267, "vemail: wnurcholis@apps.ipb.ac.id \\ ${ }^{3}$ Tropical Biopharmaca Research Center, Institut Pertanian Bogor. Jl. Taman Kencana, Bogor 16128, West Java, Indonesia
}

Manuscript received: 28 October 2019. Revision accepted: 26 November 2019.

\begin{abstract}
Aisyah SI, Muhallilin I, Sukma D, Nurcholis W. 2019. The morphological and phytochemical studies on the effect of acute and recurrent irradiation in Celosia cristata seeds. Biodiversitas 20: 3766-3771. The present work investigated the agro-morphological changes in Celosia cristata L. seeds exposed to gamma irradiations. This study also conducted phytochemical screening to screened secondary metabolite change in C. cristata. C. cristata seeds were irradiated with acute radiation at doses of 470, 480, and 490 Gy and were planted until $\mathrm{M}_{1}$ generation. Recurrent irradiation was done on $\mathrm{M}_{1}$ seeds at a dose of 250 Gy. The agro-morphological and phytochemical diversity was performed in $\mathrm{M}_{2}$ generation. The highest difference characters in acute irradiated plants were found on plant height, number of branches, and flower length, while the plant diameter, flower width, and number of flowers were found the highest in recurrent irradiation. Agro-morphological important changes in recurrent irradiated plants were decreased plant height and increased the number of flowers that compared with acute irradiated and control plants. The qualitative phytochemical showed no difference between acute and recurrent irradiated plants. It can be concluded that the recurrent irradiated changes the morphological valuable of $C$. cristata, while the phytochemical is needed further research.
\end{abstract}

Keywords: Celosia cristata, mutation, gamma radiation, acute radiation, recurrent irradiation

\section{INTRODUCTION}

Celosia cristata L., called "Jengger ayam" in Indonesia, is an ornament and herbaceous plants of the family Amaranthaceae, widely grown in Asia and Africa (Kim et al. 2015b; Sun et al. 2015). C. cristata has a unique shape and attractive colors of flowers. Thus, this plant is also popular as the ornamental plant for landscape, potted, and cut flowers. $C$. cristata is also used as a medicinal plant with several biological activities such as antioxidant activity from flower extract (Kim et al. 2015b), antiviral activity from leaves extract (Balasubrahmanyam et al. 2000), immunomodulatory activity from polysaccharide CP1-1 isolated (Sun et al. 2015), and hepatoprotective activity from saponin and triterpenoid saponin isolated ( Wang et al. 2010; Sun et al. 2011). Therefore, the diversity of morphology and metabolite in $C$. cristata needs to be increased to maximize the potential plants used as an ornamental and herb plant.

Celosia cristata is a self-pollinated plant with sexual production by seeds (UPOV 2002). Because it's a selfpollinated plant, the hybridization techniques for improving morphology and metabolite diversity of $C$. cristata need to be improved. Recently, mutation breeding in the plant has been widely used to create new plant varieties ( Zhou et al. 2015; Oladosu et al. 2016; Jankowicz-Cieslak et al. 2017). Gamma-ray irradiation is one alternative technique that advantageous (e.g., rapid, effective) to create plant mutants that potential for breeding varieties (Atay et al. 2018; Asif and Khalil Ansari 2019; Parchin et al. 2019). Recent studies have been successfully recording the use of gamma rays in improving morphology and related character changes, such as Nigella sativa (Asif and Khalil Ansari 2019), Abelmoschus esculentus (Amir et al. 2018), C. cristata plantlets (Muhallilin et al. 2019), and apple (Atay et al. 2018). Yamaguchi (1988) has found radiosensitivity of gamma-ray irradiation in $C$. cristata, in which the $\mathrm{LD}_{50}$ value is $480 \mathrm{~Gy}$.

Acute and recurrent irradiation are gamma irradiation techniques that can be used in improving genetic diversity in crops ( Mishra et al. 2007; Hong et al. 2018). Both acute and recurrent gamma irradiation methods have long been applied in seed and vegetatively propagated plants to obtain highest mutant diversity (Data 1991, Jan et al. 2011; Hong et al. 2018). Several works have been reported that impact of the radiation such as growth plant inhibition in colored wheat (Hong et al. 2018), induction of metabolite antioxidant and antioxidant enzyme activities in wheat (Hong et al. 2014), and decrease of cell wall yield, neutral sugar and lignin contents in Brachypodium distachyon (Kim et al. 2015a). However, there is little information on the impact of acute and recurrent irradiation on the agromorphology traits of $C$. cristata plant.

The objective of this work was to investigate the agromorphological traits induced by acute and recurrent gamma-ray exposure in $C$. cristata seeds. Also, we screened phytochemical change in the acute and recurrent irradiated plant. The results were showed that the recurrent 
gamma irradiation could be effectively used to change of agro-morphology valuable in commercial of $C$. cristata by comparing it with the acute irradiated and control plants.

\section{MATERIALS AND METHODS}

Celosia cristata seeds were composed during 20162017 from cultivation population in Sabisa Farm, Bogor, Indonesia. $C$. cristata was identified in the Department of Agronomy and Horticulture, Faculty of Agriculture, Bogor Agricultural University, Indonesia by the first author in this work. The seeds were acutely irradiated with gamma rays at $0,470,480$, and 490 Gy. Irradiation was done using gamma-rays apparatus equipped at the National Nuclear Energy Agency of Indonesia. One hundred fifty seeds were used for individual doses. Non-radiated and radiated seeds from each treatment were placed in growth polybag $(25 \times 25$ $\mathrm{cm})$ using media combination of soil, compost, and husk (1: 1: 1). The watering, and controlling pests and diseases were performed in cultivation plants for five weeks. The plant height, plant diameter, number of branches, number of flowers, flower length, and flower width were recorded as agro-morphological characters in M1 generation after these plants flowering ( 5 weeks after planting). After plants matured, M1 seeds were individually collected and then were recurrently irradiated with $250 \mathrm{~Gy}$. These seeds were considered as M2 generation. The seeds of control, acute irradiated (470, 480, and $490 \mathrm{~Gy}$ ) of M1 generation, and recurrent irradiated $(470+250,480+250$, and $490+250 \mathrm{~Gy})$ of M2 generation were planted in growth polybag. Some quantitative characters such as plant height, plant diameter, number of branches, number of flowers, flower length, and flower width were measured in 5 weeks after planting. The qualitative characters such as the intensity of anthocyanin coloration at the base of the stem, shape in cross-section of stem, leaf shape, and shape of leaf apex were evaluated based on set standards of UPOV for Celosia (2002). The flower color traits of plants were evaluated using the RHS mini color chart standard. Phytochemicals of flavonoids, saponins, and steroids in flower samples were screened using the general procedure (Harborne 1998).
ANOVA was performed to assess the statistical significance of the result recorded in this work. Duncan's multiple range test was used to evaluating the differences between means of data. Statistically significant was considered of $p$-value $<0.05$ and data were shown as mean value $( \pm \mathrm{SD})$.

\section{RESULTS AND DISCUSSION}

Quantitative agro-morphology from a different dose of acute gamma irradiation was investigated in the M1 generation of $C$. cristata (Table 1). The plant height (74.96 $\mathrm{cm})$, plant diameter $(1.05 \mathrm{~cm})$, number of branches $(2.49)$, number of flowers $(2.91)$, and flower length $(6.33 \mathrm{~cm})$ values were significantly lower observed in plant irradiated of 470 Gy as compared to control and irradiated with 480 and 490 Gy dose. Furthermore, the flower width was recorded not significant between all the plant treatment. Plant height, plant diameter, the number of branches, number of flowers, and flower length decreased in the M1 generations in all doses compared to the control. While, flower width at dose 470, 480, and 490 increased, compared to the control in the M1 generation. Changes in the qualitative agro-morphology of $C$. cristata in acute irradiated, as presented in Figure 1.

Table 1. The effects of acute gamma irradiation on quantitative agro-morphology in M1 generation of C. cristata

\begin{tabular}{lcccccc}
\hline $\begin{array}{c}\text { Doses } \\
\text { (Gy) }\end{array}$ & $\begin{array}{c}\text { Plant } \\
\text { height } \\
\text { (cm) }\end{array}$ & $\begin{array}{c}\text { Plant } \\
\text { diameter } \\
\text { (cm) }\end{array}$ & $\begin{array}{c}\text { Number Number Flower } \\
\text { of }\end{array}$ blowerer & $\begin{array}{c}\text { of } \\
\text { oflowers }\end{array}$ & $\begin{array}{c}\text { length } \\
\text { (cm) }\end{array}$ & $\begin{array}{c}\text { width } \\
\text { (cm) }\end{array}$ \\
\hline 0 & $93.75 \mathrm{a}$ & $1.19 \mathrm{~b}$ & $4.95 \mathrm{a}$ & $4.28 \mathrm{a}$ & $7.87 \mathrm{a}$ & 7.04 \\
470 & $74.96 \mathrm{c}$ & $1.05 \mathrm{c}$ & $2.49 \mathrm{c}$ & $2.91 \mathrm{~b}$ & $6.33 \mathrm{~b}$ & 7.13 \\
480 & $77.18 \mathrm{c}$ & $1.18 \mathrm{~b}$ & $3.61 \mathrm{~b}$ & $3.48 \mathrm{~b}$ & $6.54 \mathrm{~b}$ & 7.15 \\
490 & $86.69 \mathrm{~b}$ & $1.32 \mathrm{a}$ & $3.06 \mathrm{bc}$ & $3.19 \mathrm{~b}$ & $6.99 \mathrm{~b}$ & 7.99 \\
\hline
\end{tabular}

Note: WAP = week after planting. Different letters in column indicating statistically differences mean at $p<0.05$ by Duncan's multiple range test.

Table 2. Diversity of morphological characters in M2 generation of C. cristata

\begin{tabular}{|c|c|c|c|c|c|}
\hline Plants & $\begin{array}{c}\text { Doses } \\
(\mathbf{G y})\end{array}$ & $\begin{array}{c}\begin{array}{c}\text { Intensity of anthocyanin } \\
\text { coloration at base of } \\
\text { stem }\end{array} \\
\end{array}$ & $\begin{array}{l}\text { Shape in cross- } \\
\text { section of stem }\end{array}$ & Leaf shape & Shape of leaf apex \\
\hline Control & 0 & Strong, medium, weak & Circular, flattened & Ovate, elliptic & Short acuminate, long acuminate \\
\hline B1 9.1 & 470 & Strong & Circular & Ovate & Short acuminate \\
\hline C1 26.1 & 480 & Weak & Circular & Ovate & Short acuminate \\
\hline C1 13.3 & 480 & Medium & Circular & Ovate & Short acuminate \\
\hline D1 46.2 & 490 & Strong & Circular & Ovate & Short acuminate \\
\hline D2 15.3 & 490 & Strong & Circular & Ovate & Short acuminate \\
\hline B3 $16+250.1$ & $470+250$ & Strong & Circular & Ovate & Short acuminate \\
\hline D1 $11+250.1$ & $490+250$ & Strong & Circular & Ovate & Short acuminate \\
\hline D1 $18+250.3$ & $490+250$ & Strong & Circular & Ovate & long acuminate \\
\hline D1 $19+250.2$ & $490+250$ & Medium & Circular & Ovate & Short acuminate \\
\hline D1 $23+250.2$ & $490+250$ & Strong & Circular & Ovate & Short acuminate \\
\hline D $35+250.2$ & $490+250$ & Strong & Circular & Ovate & Short acuminate \\
\hline
\end{tabular}


Compared to the $C$. cristata control, the plant mutant of B1 8 (470 Gy), D1 7 and D1 24 (490 Gy) were showed a color change in stem and leaves with the presence of white colors (variegated) (Figure 1b). These data are in line with reported our previous work that also observed white color variegated in stem and leaves on plantlets mutation of $C$. cristata (Muhallilin et al. 2019). The plants B1 2 and B1 31, with 470 Gy dose, had higher prophylls, whereas C1 18 and C3 25 (480 Gy) were few prophylls. The C. cristata control was absent of prophylls. The stem and flower oriented at $360^{\circ}$ were recorded in plant B1 31 (470 Gy). The color of pink-purple (71 A) identified in several plant mutants. This discovery delivers important information about acute irradiated dosages that are needed to obtain desirable differences in agro-morphological characters of C. cristata. The dose of $470 \mathrm{~Gy}$ was effectively changed some qualitative agro-morphology in M1 generation of $C$. cristata.

The impact of acute and recurrent gamma irradiation on the qualitative morphological characters of $C$. cristata was evaluated in the M2 generation, which presented in Table 2. Compared to the plant control, the plant mutants from recurrent irradiation showed strong and medium in the intensity of anthocyanin coloration at the base of the stem, but weak, medium, and strong were identified in acute plant mutants. Generally, the shape in cross-section of stem, leaf shape, and shape of leaf apex was showed a similarity between acute and recurrent plant mutants. Figure 2 showed the change of qualitative traits of $C$. cristata in M2 generation. The green color was recorded in stem and also in leaves with purple in the middle of plant control. The cristate with purple 71A was showed in plant control (Figure 2a). In M2 generations, the morphological traits changed in acute and recurrent irradiation of $C$. cristata. The plant C1 26.1 that irradiated at 480 Gy was replaced becomes spicate with a light purple color (70B) in shape and colors of flowers (Figure 2b). Pink purple (71 B) of flowers was recorded in acute and recurrent $C$. cristata irradiated namely of B3 $16+250.1(470+250 \mathrm{~Gy})$, and D1 $23+250.2(490+250 \mathrm{~Gy})$, but purple (58A) was identified in B1 9.1 (470 Gy). In M2 generation, there were six plants that changed in morphological character in recurrent irradiation, but five plants recorded in acute irradiation. Therefore, recurrent irradiation is recommended to improve the morphological diversity in $C$. cristata compared to acute irradiation. The above fact was also underlined in works conducted with other plants, Triticum aestivum L. (Hong et al. 2018), and banana (Mishra et al. 2007).

The impact of acute and recurrent radiation on the qualitative morphological characters of $C$. cristata was evaluated M2 generation.

The effects of acute and recurrent irradiation on the quantitative agro-morphology were detectable in the M2 generation (Figure 3). All characters changed in the acute and recurrent irradiated plant as compared to the control. In the box-and-whisker plots (Figure 3), the highest variation was measured in character of plant height, number of branches, and flower length which found in the acute irradiated plant. The plant diameter, flower width, and a number of flower traits were found highest diversity in the recurrent irradiated plant. The plant height ranged from $44.93 \mathrm{~cm}$ (recurrent irradiated, $470+250 \mathrm{~Gy}$ ) to 84.70 (control) $\mathrm{cm}$. The plant diameter ranged from $1.16 \mathrm{~cm}$ (control) to $1.54 \mathrm{~cm}$ (acute irradiated, $490 \mathrm{~Gy}$ ). Number of branches ranged from 5.22 (recurrent irradiated, $480+250$ Gy) to 8.94 (acute irradiated, $480 \mathrm{~Gy}$ ). In the flower of width, maximum and minimum were recorded in recurrent irradiated plants at doses of $490+250$ and $470+250$ Gy with value of $8.50 \mathrm{~cm}$ and 5.96, respectively. Number of flower ranged from 8.64 (recurrent irradiated, $470+250$ Gy) to 3.67 (recurrent irradiated, $480+250$ Gy). Flower length trait ranged from $7.62 \mathrm{~cm}$ (control) to $11.18 \mathrm{~cm}$ (acute irradiated, 480 Gy). Shorted of plant height and higher of number of flowers in $C$. cristata are important noticed agro-morphology of commercial value as the ornamental plants (Tawila 2018). Interestingly, recurrent irradiated plant decreased plant height and also increased number of flowers compared with acute irradiated and control plants. These results indicated that the recurrent irradiated plants could be exploited in breeding programs for the development of ornamental plant varieties.

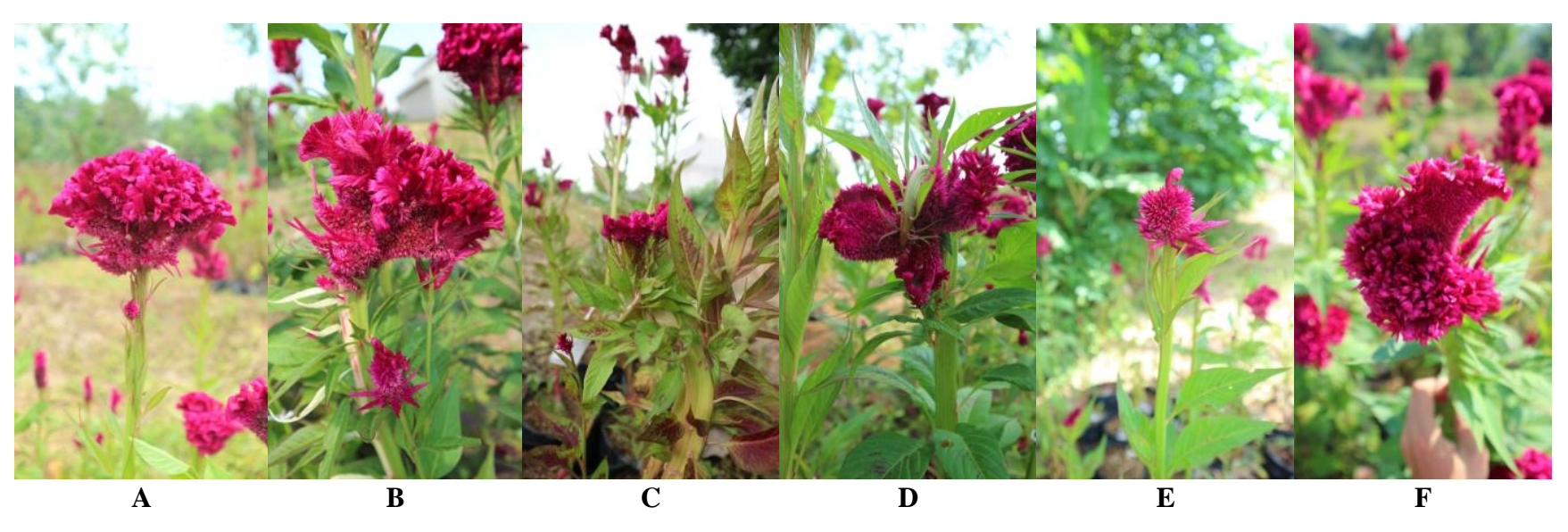

Figure 1. Diversity of qualitative morphology in control (A) and M1 generation of acute irradiated D1 7 (B), C2 31 (C), B1 31 (D), C1 18 (E), and C3 25 (F) of C. cristata plants 

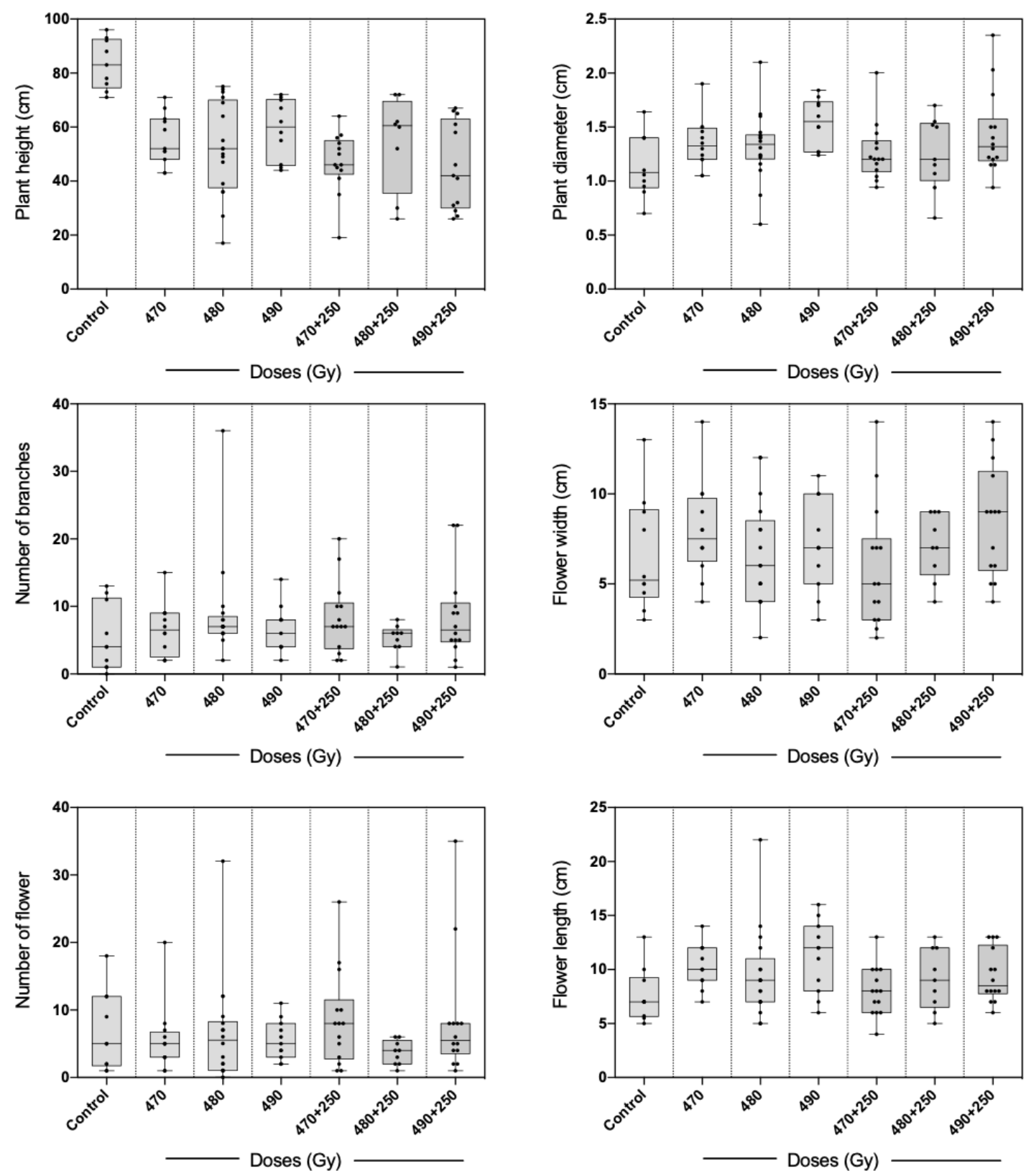

Figure 2. Boxplot of several characters on M2 generation of C. cristata plants

As an additional analysis, we also evaluated the phytochemical qualitative content in $\mathrm{M} 2$ generation of $C$. cristata and it is presented in Table 3. Previous study reported that the flavonoids, saponins, and steroids identified in flower of mutated C. cristata (Muhallilin et al. 2019). Therefore, we conducted these compounds for our sample. Generally, qualitative metabolites detected no difference between acute and recurrent irradiated plants. Saponins and steroids were identified in acute and recurrent irradiated plants, while flavonoids only detected in B2 8.1 (acute irradiated, $470 \mathrm{~Gy}$ ) and C1 $11+250.1$ (recurrent irradiated, $480+250$ Gy) plants. In control plant, all metabolite was detected. These data agreed with previous work in the control plant of $C$. cristata flower (Muhallilin et al. 2019). Mishra et al. (2007) studied gamma radiation treatment that activated glucomoringin content, an anticancer metabolite, in Moringa oleifera. Glucomoringin and related molecules content were increased in the $M$. oleifera irradiation. In this regard, our results showed that there was no difference in phytochemical content between acute and recurrent irradiated plant of $C$. cristata. Therefore, further work is needed to evaluation of phytochemical compounds related to pharmacological activities in $C$. cristata irradiated plants. As reported Parchin et al. (2019), gamma irradiation on Iranian fenugreek is improved the growth characters and accumulated valuable bioactive. Khattak and Rahman (2016) also reported application of the gamma irradiation on Ziziphus mauritiana which improved the level of phytochemical, antimicrobial, and antioxidant activities. 


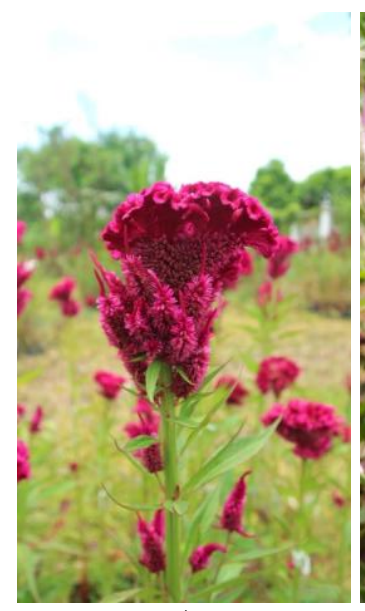

A

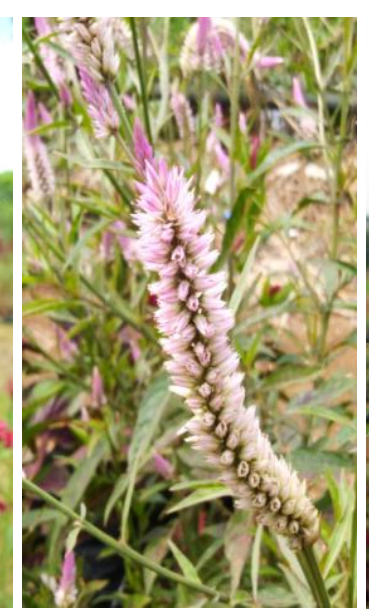

B

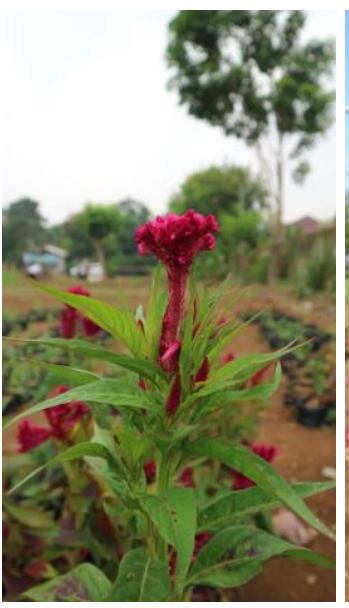

C

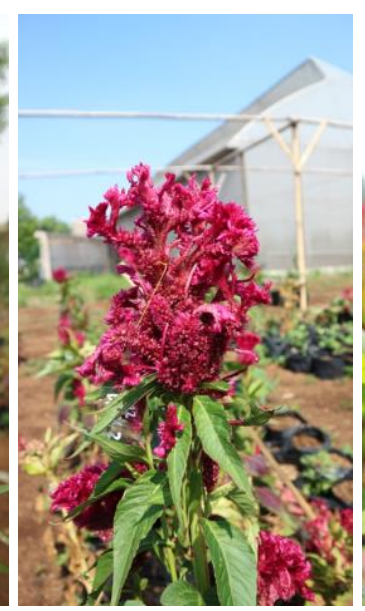

D

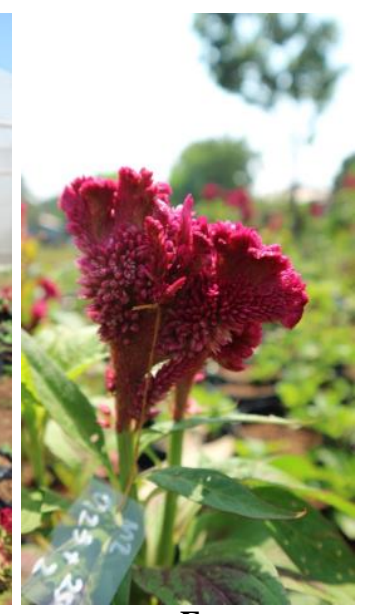

E

Figure 3. Diversity of qualitative morphology in (a) control plant, M1 generation of acute irradiated plants (b) C1 26.1 (480 Gy) and (c) B1 9.1 (470 Gy), and M2 generation recurrent irradiated plants (d) B3 16+250.1 (470+250 Gy) and (e) D1 23+250.2 (490+250 Gy) of C. cristata

Table 3. Diversity of phytochemical screening in M2 generation of C. cristata

\begin{tabular}{|c|c|c|c|c|}
\hline Plants & $\begin{array}{c}\text { Doses } \\
\text { (Gy) }\end{array}$ & Flav. & Sap. & Ster. \\
\hline Control & 0 & + & + & + \\
\hline B2 8.1 & 470 & + & + & + \\
\hline B2 24.1 & 470 & - & + & + \\
\hline B3 33.1 & 470 & - & + & + \\
\hline C1 26.1 & 480 & - & + & + \\
\hline C2 16.1 & 480 & - & - & + \\
\hline C2 36.1 & 480 & - & + & + \\
\hline D2 15.3 & 490 & - & + & + \\
\hline D1 46.2 & 490 & - & + & + \\
\hline D2 47.1 & 490 & - & + & + \\
\hline B2 $31+250.1$ & $470+250$ & - & + & + \\
\hline B2 $31+250.2$ & $470+250$ & - & + & + \\
\hline B2 $33+250.4$ & $470+250$ & - & + & + \\
\hline B3 $16+250.1$ & $470+250$ & - & + & + \\
\hline $\mathrm{C} 17+250.3$ & $480+250$ & - & + & + \\
\hline C1 $26+250.1$ & $480+250$ & - & + & + \\
\hline $\mathrm{C} 111+250.1$ & $480+250$ & + & + & + \\
\hline C1 $15+250.1$ & $480+250$ & - & + & + \\
\hline D1 $19+250.1$ & $490+250$ & - & + & + \\
\hline D1 $18+250.2$ & $490+250$ & - & + & + \\
\hline D1 $23+250.2$ & $490+250$ & - & + & + \\
\hline $\mathrm{D} 32+250.1$ & $490+250$ & - & + & + \\
\hline
\end{tabular}

Note: - = not identified; $+=$ identified. Flav: Flavonoids, Sap: Saponins, Ster: Steroids

The agro-morphological traits of $C$. cristata were changed in acute and recurrent gamma irradiated. Moreover, recurrent irradiated $C$. cristata plants were shown to enhanced agro-morphological commercial valuable characters such as shorter in plant height and highest in number of flowers. Flavonoids, saponins, and steroids were screened not difference between acute and recurrent irradiated plants. Therefore, further research is needed to evaluate the metabolite profile in $C$. cristata irradiated.

\section{ACKNOWLEDGEMENTS}

This work was supported by the Ministry of Research, Technology and Higher Education of the Republic of Indonesia (Grant No. 4172/IT3.L1/PN/2019). Also, the authors gratefully thank Prof. Dr. Husin Alatas for his valuable suggestion that facilitated in improving the manuscript. Finally, the authors would also like to thank DPIS IPB University for finishing manuscript by "PubliCamp" program in 2019

\section{REFERENCES}

Amir K, Hussain S, Shuaib M, Hussain F, Urooj Z, Khan WM, Zeb U, Ali K, Zeb MA, Hussain F. 2018. Effect of gamma irradiation on OKRA (Abelmoschus esculentus L.). Acta Ecol Sin 38: 368-373.

Asif A, Khalil Ansari MY. 2019. Generation of mutant lines of Nigella sativa L. by induced mutagenesis for improved seed yield. Ind Crops Prod 139: 111552.

Atay AN, Atay E, Lauri P-E, Kunter B, Kantoglu KY. 2018. Phenotyping gamma-ray-induced mutant population of 'Amasya' apple for architectural traits, precocity, floral phenology, and fruit characteristics. Sci Hortic (Amsterdam) 233: 195-203.

Balasubrahmanyam A, Baranwal VK, Lodha ML, Varma A, Kapoor HC. 2000. Purification and properties of growth stage-dependent antiviral proteins from the leaves of Celosia cristata. Plant Sci 154: 13-21.

Data S. 1991. Evaluation of recurrent irradiation on vegetatively propagated ornamentals: chrysanthemum. J Nucl Agric Biol 20: 8186.

Harborne AJ. 1998. Phytochemical methods, a guide to modern techniques of plant analysis. Chapman and Hall, London.

Hong MJ, Kim J-B, Yoon YH, Kim SH, Ahn J-W, Jeong IY, Kang S-Y, Seo YW, Kim DS. 2014. The effects of chronic gamma irradiation on oxidative stress response and the expression of anthocyanin 
biosynthesis-related genes in wheat (Triticum aestivum). IntL J Radiat Biol 90: 1218-1228.

Hong MJ, Kim DY, Ahn J-W, Kang S-Y, Seo YW, Kim J-B. 2018. Comparison of radiosensitivity response to acute and chronic gamma irradiation in colored wheat. Genet Mol Biol 41: 611-623.

Jan S, Parween T, Siddiqi and TO, Mahmooduzzafar N. 2011. Effect of gamma radiation on morphological, biochemical, and physiological aspects of plants and plant products. Environ Rev 20: 17-39.

Jankowicz-Cieslak J, Mba C, Till BJ. 2017. Mutagenesis for crop breeding and functional genomics. In: Biotechnologies for Plan Mutation Breeding. Springer, Cham.

Khattak KF, Rahman TU. 2016. Effect of gamma irradiation on the vitamins, phytochemicals, antimicrobial and antioxidant properties of Ziziphus mauritiana Lam. leaves. Radiat Phys Chem 127: 243-248.

Kim JY, Na CS, Kim DS, Kim J-B, Seo YW. 2015a. indu. Cellulose 22 2419-2430.

Kim Y-S, Hwang J-W, Sung S-H, Jeon Y-J, Jeong J-H, Jeon B-T, Moon S-H, Park P-J. 2015b. Antioxidant activity and protective effect of extract of Celosia cristata L. flower on tert-butyl hydroperoxideinduced oxidative hepatotoxicity. Food Chem 168: 572-579.

Mishra PJ, Ganapathi TR, Suprasanna P, Bapat VA. 2007. Effect of Single and Recurrent Gamma Irradiation on in vitro Shoot Cultures of Banana. IntL J Fruit Sci 7: 47-57.

Muhallilin Ii, Aisyah SI, Sukma D. 2019. The diversity of morphological characteristics and chemical content of Celosia cristata plantlets due to gamma-ray irradiation. Biodiversitas 20: 862-866.
Oladosu Y, Rafii MY, Abdullah N, Hussin G, Ramli A, Rahim HA, Miah G, Usman M. 2016. Principle and application of plant mutagenesis in crop improvement: a review. Biotechnol Biotechnol Equip 30: 1-16.

Parchin RA, Ghomi AAN, Badi HN, Eskandari A, Navabpour S, Mehrafarin A. 2019. Growth characteristics and phytochemical responses of Iranian fenugreek (Trigonella foenum-graecum L.) exposed to gamma irradiation. Ind Crops Prod 139: 111593.

Sun Z-L, Gao G-L, Xia Y-F, Feng J, Qiao Z-Y. 2011. A new hepatoprotective saponin from semen Celosia cristatae. Fitoterapia 82: 591-594.

Sun Z, Peng Y, Zhao W-W, Xiao L-L, Yang P-M. 2015. Purification, characterization and immunomodulatory activity of a polysaccharide from Celosia cristata. Carbohydr Polym 133: 337-344.

Tawila ASI. 2018. Stunting of cock's comb (Celosia cristata L.) plants. Middle East J 7: 83-99.

UPOV. 2002. Guidelines for The Conduct of Tests for Distinctness, Uniformity and Stability: Celosia L. International Union for the Protection of New Varieties of Plants, Geneva.

Wang Y, Lou Z, Wu Q-B, Guo M-L. 2010. A novel hepatoprotective saponin from Celosia cristata L. Fitoterapia 81: 1246-1252.

Yamaguchi T. 1988. Mutation breeding of ornamental plants. Hoshasen Ikushujo Kenkyu Hokoku 7: 49-67.

Zhou W, Wu Z, Zhang Y, Wu D, Liu D, Wang Y, Gao Q, Dang B, Li W, Hou S. 2015. Stable inheritance of excellent agricultural traits induced by $12 \mathrm{C} 6+$ heavy-ions in lentil (Lens culinaris Medik.). Czech J Genet Plant Breed 51: 29-35. 